\title{
Health care promises fly during New Brunswick election campaign
}

Published at www.cmaj.ca on Sept. 21

$\mathrm{M}$ ore doctors, nurses and health clinics, a new air ambulance, a diabetes strategy and a universal prescription drug program.

The list of health care goodies promised in the run-up to New Brunswick's Sept. 27 election is lengthy - and expensive, leaving many, including some of the promisors, wondering if the province can really afford the campaign pledges.

Health care spending typically rises $6 \%-8 \%$ a year, while provincial revenues creep up $1 \%-2 \%$, notes Progressive Conservative leader David Alward. But that discrepancy hasn't stopped him from promising a minimum $3 \%$ increase in the health department's budget.

Alward, the Official Opposition leader, would use $\$ 3.5$ million per year to double the number of physicians trained in the province and combat the "severe" doctor shortage. It's "unacceptable" that 60000 of New Brunswick's 750000 residents are without a family doctor, he says.

The Conservatives would also establish new health clinics and a diabetes strategy. But their biggest ticket item (\$20 million) would involve the creation of a provincial plan for catastrophic drug costs to help the $29 \%$ of New Brunswickers, including one in five seniors, who they say are without drug coverage.

Alward says the diabetes strategy will save money in the long run but admits that funding such health measures will be a challenge in the face of the province's \$750-million deficit and ballooning health costs. Health department outlays have soared $30 \%$ in four years (to $\$ 2.45$ billion from $\$ 1.9$ billion in fiscal 2006-07) and now comprise $30 \%$ of the government's $\$ 8$-billion budget.

But Alward says he'll achieve some wiggle room by shrinking the cabinet,



New Brunswick Premier Shawn Graham promises to introduce universal pharmacare if re-elected.

scrapping planned tax cuts and slashing at least $\$ 150$ million per year in government waste. "We've got to start getting our spending under control and we can't do that unless we reduce the size of government."

Liberal Premier Shawn Graham calls the Conservative platform an unaffordable foray into future health care cuts.

His solution?

More of the same: more doctors and less duplication.

Graham says the Liberals delivered 170 more doctors to the province since assuming office in 2006 and proposes to add 55 new physician billing numbers over the next two years. The Grits will also double the number of primary care clinics to 30 and the number of nurse practitioners from 55 to 110 .

Also on their \$20-million health care promise list: a new air ambulance for northern rural areas, 550 advanced-care beds to move seniors out of hospital wards and universal pharmacare.
How would Graham do so within the confines of the tight budget?

First off, more efficiency on the order of his amalgamation of regional health authorities from eight to two. If re-elected, Graham would focus on better management of the "spiralling costs" of treating chronic diseases, which gobble up two-thirds of the health budget. He also pledges to create 20000 jobs over the next four years, which would bolster provincial coffers.

Such promises often rest on shaky financial foundations but aren't unusual during election campaigns, says Michael Decter, founding chair of the Health Council of Canada. "Modest" promises, like a new air ambulance, probably won't drain government coffers, Ontario's former deputy health minister adds.

But Graham and Alward's ability to pay for major initiatives like universal pharmacare will likely hinge on federal generosity and the outcome of future intergovernmental negotiations on the 
level of Canada Health Transfers after fiscal 2013/14, Decter says.

"You're going to need a strong economy and some federal help to do catastrophic drugs," Decter says, noting such a program would cost New Brunswick hundreds of millions of dollars alone.

Dr. Chris Losier, president of the New Brunswick Medical Society, says the politicians must also grapple with an even larger question: Is the health care system sustainable given its fiscal state and the province's aging population?
The Moncton emergency department physician says that, left unchecked, the system will eventually gobble up $60 \%$ of the province's budget. "That certainly doesn't sound sustainable. That is a concern," he says. "It's not necessarily about spending more money on health care; it's about trying to be more efficient.'

The society wants the parties to offer solutions to resolve the province's long-term care "crisis," as well as the removal of the current limit on billing numbers (which are now pre-assigned annually to areas of the province).

The current billing system is hampering efforts to solve the physician shortage, Losier says. "Sadly, we've had no commitment from any of the parties to remove the billing number restrictions. We're the only province in the country that does this and it puts us at a tremendous disadvantage. It's a loser, let's get rid of it." — Quentin Casey, Halifax, NS

DOI:10.1503/cmaj.109-3677 